\title{
Molecular cloning and expression of human $\mathrm{EP}_{3}$ receptors: evidence of three variants with differing carboxyl termini
}

\author{
${ }^{1}$ J.W. Regan, T.J. Bailey, *J.E. Donello, K.L. Pierce, D.J. Pepperl, D. Zhang, ${ }^{*}$ K.M. Kedzie, \\ ${ }^{*}$ C.E. Fairbairn, *A.M. Bogardus, *D.F. Woodward \& *D.W. Gil
}

Departments of Pharmacology \& Toxicology, and Physiology and the Program in Neuroscience, University of Arizona, Tucson, AZ 85721 and *Allergan, Inc., Biological Sciences, Irvine, CA 92713, U.S.A.

1 The polymerase chain reaction (PCR) was used in combination with plaque hybridization analysis to clone four variants of the $\mathrm{EP}_{3}$ prostaglandin receptor from a human small intestine cDNA library. 2 Three of these variants, i.e. the $\mathrm{EP}_{3 \mathrm{~A}}, \mathrm{EP}_{3 \mathrm{E}}$ and $\mathrm{EP}_{3 \mathrm{D}}$, share the same primary amino acid sequence except for their carboxyl termini, which diverge from one another at the same point, approximately 10 amino acids away from the end of the seventh membrane spanning domain of the receptor. The fourth variant $\left(\mathrm{EP}_{3 \mathrm{Al}}\right)$ has a nucleotide coding sequence identical to $\mathbf{E P}_{3 \mathrm{~A}}$ but has a completely different $3^{\prime}$ untranslated sequence.

3 The carboxyl termini of the three isoforms differ most obviously in length with the $\mathrm{EP}_{3 \mathrm{~A}}$ being the longest (41 amino acids) and the $\mathrm{EP}_{3 \mathrm{E}}$ being the shortest (16 amino acids). They also differ in content with the $\mathrm{EP}_{3 \mathrm{~A}}$ containing 9 serine and threonines in its carboxyl terminus and the $\mathrm{EP}_{3 \mathrm{E}}$ none.

4 Transient expression in eukaryotic cells showed that the human $\mathrm{EP}_{3}$ receptor variants had similar but not identical radioligand binding properties and differed in their functional coupling to second messenger pathways. Up to $3 \mathrm{pmol} \mathrm{mg}^{-1}$ protein of $\left[{ }^{3} \mathrm{H}\right]$-prostaglandin $\mathrm{E}_{2}$ binding could be obtained with more than $95 \%$ specific binding. Using a reporter gene assay, as a measure of intracellular cyclic AMP levels, the $\mathrm{EP}_{3 \mathrm{~A}}$ coupled more efficiently to the inhibition of adenylyl cyclase than did the $\mathrm{EP}_{3 \mathrm{E}}$.

5 PCR was used to confirm the presence of mRNAs encoding the four human $\mathrm{EP}_{3}$ receptor variants in tissues of the human small intestine, heart and pancreas. These findings indicate that the $\mathbf{E P}_{3}$ receptor variants identified here are likely to be expressed in tissues. The differences in the carboxyl termini at the protein level, and in the $3^{\prime}$ untranslated regions at the mRNA level, could be profound in terms of the regulation and functional coupling of these receptor isoforms.

Keywords: Prostaglandin; small intestine; cDNA; G-protein coupled; adenylyl cyclase; cyclic AMP inhibition; CAT assays

\section{Introduction}

The prostaglandins are locally acting hormones derived from the metabolism of arachidonic acid by prostaglandin endoperoxide synthase (cyclo-oxygenase). They are very widely distributed in animal tissues where they act on cell surface receptors to produce a diverse range of physiological effects. The prostaglandin receptors elicit cellular responses by activating guanine nucleotide regulatory proteins (G-proteins). Like other members of the superfamily of G-protein coupled receptors their molecular structure is dominated by seven hydrophobic regions that appear to represent membrane-spanning $\alpha$-helices.

The prostanoid receptor family is comprised of several members according to the current classification (Coleman $e t$ al., 1982). Separate receptors for prostaglandin $\mathrm{D}_{2}\left(\mathrm{PGD}_{2}\right)$, $\mathrm{PGE}_{2}, \mathrm{PGF}_{2 \alpha}, \mathrm{PGI}_{2}$ and thromboxane $\mathrm{A}_{2}$ were originally proposed based largely on agonist studies: these receptors were respectively defined as DP, EP, FP, IP and TP. This classification received further support by the development of TP (Coleman et al., 1982) and DP receptor (Giles et al., 1989) antagonists. A further subdivision of EP receptors into 3 subtypes $\left(\mathrm{EP}_{1}, \mathrm{EP}_{2}\right.$ and $\left.\mathrm{EP}_{3}\right)$ was proposed based on functional studies and by the development of an EP receptor antagonist (Coleman et al., 1982; 1987). Similar heterogeneity of the other prostanoid receptors appears likely. Thus, subdivisions within the TP (Masuda et al., 1991; Furci et al., 1992) and DP receptors (Woodward et al., 1993) have been suggested.

${ }^{1}$ Author for correspondence.
The advent of a more detailed classification of the prostaglandin receptors came with the cloning of a human TP receptor (Hirata et al., 1991). Its deduced amino acid sequence confirmed that the TP receptors are in the superfamily of G-protein coupled receptors and provided the basis for the subsequent cloning of the mouse $\mathrm{EP}_{2}$ (Honda et al., 1993) and $\mathrm{EP}_{3}$ receptors (Sugimoto et al., 1992). The subsequent cloning of two isoforms of the mouse $\mathrm{EP}_{3}$ receptor revealed heterogeneity that was not anticipated by previous functional studies (Sugimoto et al., 1993). With respect to their deduced amino acid sequences, the two isoforms, $\mathrm{EP}_{3 \alpha}$ and $\mathbf{E P}_{3 \beta}$, differ only in the sequence of their carboxylterminal domains, this difference affecting approximately 30 amino acids changes both the interaction of these receptor isoforms with G-proteins and their patterns of agonistpromoted desensitization (Negishi et al., 1993).

An important benefit of having a cloned receptor is the ability to study its pharmacology in the absence of potentially interfering receptors by the use of heterologous expression. Such types of studies have revealed significant species differences in the pharmacology of cloned rodent G-protein coupled receptors as compared with their human homologues. It has been found that a change in just one amino acid is sufficient to cause differences. For example, the rat $5-\mathrm{HT}_{1 \mathrm{~B}}$ and human $5-\mathrm{HT}_{1 \mathrm{D}}$ receptors are actually biochemical homologues but a ${ }^{355} \mathrm{~T} \rightarrow \mathrm{N}$ mutation in transmembrane (TM) 7 of the human $5-\mathrm{HT}_{\mathrm{ID}}$ changes its pharmacology to the extent that these receptors came to be defined as different subtypes (Oksenberg et al., 1992). Similarly, a ${ }^{201} \mathrm{~S} \rightarrow \mathrm{C}$ mutation in TM5 of the mouse $\alpha_{2 \mathrm{~A}}$ adrenoceptor dramatically 
increases its affinity for the antagonist yohimbine relative to the human $\alpha_{2 \mathrm{~A}}$ (Link et al., 1992). This is significant because $\left[{ }^{3} \mathrm{H}\right]$-yohimbine is one of the main radioligands for the characterization of $\alpha_{2}$-adrenoceptors. To improve our understanding of the pharmacology of the human $\mathrm{EP}_{3}$ receptors we sought to clone and express these receptors. Using the polymerase chain reaction (PCR) and homology-based screening we found four human variants of this receptor. Three of the variants represent changes at the protein level and one at the mRNA level. One of the variants corresponds to the mouse $\mathrm{EP}_{3 \alpha}$ but the other three do not correspond to any of the previously described mouse $\mathrm{EP}_{3}$ receptors.

\section{Methods}

\section{Reverse transcription/PCR}

A sense primer was designed from nucleotides (nt's) 301-326 of the published mouse $\mathrm{EP}_{3}$ receptor sequence (Sugimoto et al., 1992) and corresponds to the proposed first extracellular loop of the receptor. Its sequence is:

\section{${ }^{s^{\prime}} \mathrm{GA}(\mathrm{T} / \mathrm{C}) \mathrm{CC}$ GTCG$(\mathrm{T} / \mathrm{G})$ GICGI CTITG (C/T)(C/A)(C/G)ITT ${ }^{3^{\prime}}$}

An antisense primer was designed from nucleotides 775-797 of the published mouse $\mathrm{EP}_{3}$ receptor sequence (Sugimoto et $a l ., 1992)$ and corresponds to the proposed sixth transmembrane domain of the receptor. Its sequence is:

\section{${ }^{s}$ AC(A/G)CA CATIA T(A/T/G/C)CCC AT(A/T/G/C)A(A/G) (T/C)TG ${ }^{3^{\prime}}$}

The sense and antisense primers were used in a combined reverse transcription/PCR reaction with total RNA from human small intestine (Clontech). The reverse transcription reaction (final volume, $140 \mu \mathrm{l}$ ) contained $14 \mu \mathrm{l} 10 \times$ PCR buffer (Perkin Elmer), 3.5 $\mu$ l RNasin (Boehringer Mannheim, $\left.40 \mathrm{u} \mathrm{ul}^{-1}\right), 35 \mu \mathrm{l}$ dNTP's $(5 \mathrm{mM}), 7 \mu \mathrm{l}$ random primers ( $\left.1 \mathrm{mg} \mathrm{ml}^{-1}\right), 14 \mu \mathrm{l}$ RNA $\left(1 \mu \mathrm{g} \mu \mathrm{l}^{-1}\right)$ and $7 \mu \mathrm{l}$ AMV reverse transcriptase (Boehringer Mannheim, $25 \mathrm{u}^{-1} \mathrm{l}^{-1}$ ). The reaction was incubated at room temperature $\left(\sim 24^{\circ} \mathrm{C}\right)$ for $10 \mathrm{~min}$, $42^{\circ} \mathrm{C}$ for $1 \mathrm{~h}, 95^{\circ} \mathrm{C}$ for $5 \mathrm{~min}$ and was placed on ice. The PCR reaction (final volume, $50 \mu \mathrm{l}$ ) contained $20 \mu \mathrm{l}$ from the reverse transcription reaction, $3 \mu \mathrm{l} 10 \times$ PCR buffer, $5 \mu l$ dimethylsulphoxide (DMSO), $5 \mu \mathrm{l}$ sense primer $(20 \mu \mathrm{M}), 5 \mu \mathrm{l}$ antisense primer $(20 \mu \mathrm{M})$ and $1 \mu \mathrm{l}$ Taq polymerase (Perkin Elmer, $2.5 \mathrm{u}^{-1}$ ). The following programme was used for the PCR: $94^{\circ} \mathrm{C}, 3 \mathrm{~min} ; 50^{\circ} \mathrm{C}, 2 \mathrm{~min} ; 72^{\circ} \mathrm{C}, 3 \mathrm{~min}$; followed by 59 cycles of $94^{\circ} \mathrm{C}, 1 \mathrm{~min} ; 50^{\circ} \mathrm{C}, 2 \mathrm{~min} ; 72^{\circ} \mathrm{C}, 3 \mathrm{~min}$; and a final cycle of $72^{\circ} \mathrm{C}, 15 \mathrm{~min} ; 4^{\circ} \mathrm{C}, 12 \mathrm{~h}$.

Agarose gel electrophoresis of a sample $(15 \mu \mathrm{l})$ of the PCR reaction showed a single product of $\sim 500$ base pairs (bp). The product was purified (Geneclean, Biol01 Inc.) and was cloned into pBluescript-II $\mathrm{KS}(+)$ (Stratagene) using a $\mathrm{G} / \mathrm{C}$ tailing reaction according to the manufacturer's instructions (Boehringer Mannheim). Briefly, terminal transferase was used to add a poly-dC extension on the purified PCR product and a poly-dG extension on PstI digested pBluescript. The samples were annealed and were used to transform $E$. coli $\mathrm{DH} 10 \mathrm{~B}$ cells by electroporation. A positive clone $\left(\mathrm{B}_{1}\right)$ was obtained and the nucleotide sequence of the PCR product/insert was determined using $\triangle T$ Taq-PCR sequencing according to the manufacturer's instructions (United States Biochemicals). The sequence of clone $B_{1}$ shared $\sim 80 \%$ identity with the mouse $\mathrm{EP}_{3}$ receptor and was consistent with its being a human homologue.

\section{Isolation of a genomic clone}

A human genomic library in $\lambda$ FixII (Stratagene) was screened by plaque hybridization analysis (Sambrook et al., 1989) using a ${ }^{32} \mathrm{P}$-labelled probe derived from clone $\mathbf{B}_{1}$. Nitrocellulose filters were used to take impressions of 440,000 recombinants $(\sim 20,000$ recombinants/filter $)$ which were denatured, neutralized and baked for $2 \mathrm{~h}$ at $80^{\circ} \mathrm{C}$. The filters were prehybridized for $2 \mathrm{~h}$ at $37^{\circ} \mathrm{C}$ in $50 \%$ formamide/1 $\mathrm{M}$ $\mathrm{NaCl} / 1 \% \mathrm{SDS} / 100 \mu \mathrm{g} \mathrm{ml}^{-1}$ herring sperm DNA and then hybridized with the probe overnight at $37^{\circ} \mathrm{C}$ in the same solution. The probe was labelled by nick-translation (Gibco/ BRL) and was used at a concentration of $\sim 5 \times 10^{6}$ d.p.m. $\mathrm{ml}^{-1}$. The filters were washed for $1 \mathrm{~h}$ at $37^{\circ} \mathrm{C}$ in $2 \times \mathrm{SSC} /$ $0.1 \%$ SDS and then for $1 \mathrm{~h}$ at $53^{\circ} \mathrm{C}$ in $0.1 \times \mathrm{SSC} / 0.1 \%$ SDS. Autoradiographs were obtained and a positive clone was identified $\left(\mathrm{EP}_{3} \lambda 12\right)$ and was isolated following 2 additional rounds of plaque hybridization analysis.

DNA was prepared from plate lysates of $\mathrm{EP}_{3} \lambda 12$ using LambdaSorb (Promega). The DNA was digested with EcoRI and an insert of $\sim 13$ kilobasepairs $(\mathrm{kb})$ was obtained. Further restriction enzyme analysis and Southern blotting (Sambrook et al., 1989) revealed a $2.4 \mathrm{~kb}$ BamHI fragment that hybridized with the ${ }^{32} \mathrm{P}$-labelled PCR product. This $2.4 \mathrm{~kb}$ BamHI fragment was subcloned into pBluescript and its nucleotide sequence was determined using Sequenase (United States Biochemicals). An open reading frame was present that had $\sim 80 \%$ identity with the mouse $\mathrm{EP}_{3}$ receptor sequence. The amino terminus of this open reading frame started in approximately the same region as that of the mouse $\mathrm{EP}_{3}$ amino terminus but the carboxyl terminus of the human sequence ended at a point equivalent to TM6 of the mouse $\mathrm{EP}_{3}$ receptor. Examination of the nucelotide sequence in this region of the human genomic clone was consistent with an intron/exon boundary.

\section{Isolation of $c D N A$ clones}

A human small intestine cDNA library in $\lambda \mathrm{gt} 10$ (Clontech) was screened with the nick-translated PCR product using the same conditions as described above for the genomic library. From $\sim 860,000$ recombinants, 2 clones were obtained $\left(\mathrm{EP}_{3} 27\right.$ and $\left.\mathrm{EP}_{3} 32\right)$. Another $\sim 460,000$ recombinants were screened under the same conditions except that the filters were washed for $1 \mathrm{~h}$ at $50^{\circ} \mathrm{C}$ in $1 \times \mathrm{SSC} / 0.1 \% \mathrm{SDS}$. Four clones were obtained $\left(\mathrm{EP}_{3} 1, \mathrm{EP}_{3} 4, \mathrm{EP}_{3} 19\right.$ and $\left.\mathrm{EP}_{3} 21\right)$. All were subcloned into the EcoRI site of pBluescript and were found to contain nucleotide sequence identical to the genomic clone. Although none contained complete open reading frames, between the six clones three distinct alternative splicing variants were present and complete open reading frames could be constructed for all of them (see below). A third screen of $\sim 500,000$ recombinants yielded a clone $\left(\mathrm{EP}_{3} 11.2\right)$ that represented a fourth alternative splicing variant and which contained a complete open reading frame. The latter was obtained using a ${ }^{32} \mathrm{P}$-labelled RNA probe corresponding to nt's 506-952 (Figure 1) of the genomic clone. Filters were prehybridized at $60^{\circ} \mathrm{C}$ in $6 \times \mathrm{SSC} / 20 \mathrm{mM} \mathrm{NaH} \mathrm{PO}_{4}(\mathrm{pH} \mathrm{7.6)}$ $1 \times$ Denhardts $/ 1 \mathrm{mM} \mathrm{DTT} / 100 \mu \mathrm{g} \mathrm{ml}^{-1}$ poly-A (United States Biochemical) and were hybridized overnight in the same solution containing $2 \times 10^{6}$ d.p.m. ml ${ }^{-1}$ of the probe. Filters were washed under increasingly stringent conditions with the final wash at $60^{\circ} \mathrm{C}$ for $20 \mathrm{~min}$ in $0.1 \times \mathrm{SSC} / 0.1 \% \mathrm{SDS}$. $\mathrm{EP}_{3} 11.2$ was plaque purified and subcloned into the EcoRI site of pBluescript.

\section{Full length plasmids encoding human $E P_{3}$ receptors}

A sense PCR primer containing adjacent BstXI and SspI restriction sites was made to nucleotide sequence upstream of the apparent translation start site (nt 57 in Figure 1). The sequence of this primer, shown below, contained sequence identical to that in the cDNA and genomic clones (nt's 1-22 in Figure 1) as well as additional $5^{\prime}$ sequence (the additional sequence is shown below in the smaller font, the BstXI site is bold and the SspI site is underlined).

$5^{\prime}$ GATCCACCGCGGTGGAATATTGCCCCCTCCCGCTGCGGCTCT ${ }^{3}$ 
This primer was used with an antisense primer (corresponding to nt's 657-679 in Figure 1) in a PCR reaction with the $2.4 \mathrm{~kb}$ BamHI genomic clone as a template. A product of $\sim 700$ bp was obtained that was purified with Geneclean (Bio101) and digested with BstXI, cleaving it at the $5^{\prime}$ end and at a position corresponding to nt's $499-510$ in Figure 1. The larger, $\sim 500 \mathrm{bp}$, fragment was isolated from a lowmelting-point agarose gel and was used in a solid phase ligation (Sambrook et al., 1989) with the $4.2 \mathrm{~kb}$ fragment isolated from the digestion of the pBluescript $\mathrm{EP}_{3} 27$ cDNA clone with BstXI. $\left[\mathrm{EP}_{3} 27\right.$ starts at a position corresponding to nt 497 in Figure 1 and thus contains the downstream BstXI site as well as BstXI site immediately upstream in the multiple cloning site of pBluescript.] $E$. coli XL1-Blue cells were transformed and a clone was obtained $\left(\mathrm{KS} / \mathrm{EP}_{3 \mathrm{~A}}\right.$, Figure 1) containing 1170 bases of the complete open reading frame, 56 bases of $5^{\prime}$-untranslated sequence and 504 bases of 3'untranslated sequence. $\mathrm{KS} / \mathrm{EP}_{3 \mathrm{~A}}$ was digested with $\mathrm{SspI}$ and the coding fragment was ligated to EcoRV digested pBluescript to yield KS/EPS in which the orientation of the coding sequence was such that the translation start site (nt's 57-59) was downstream of the T3 promotor.

A full length construct of $\mathrm{EP}_{3 \mathrm{E}}\left(\mathrm{KS} / \mathrm{EP}_{3 \mathrm{E}}\right)$ was obtained by digesting the pBluescript clone of $\mathrm{EP}_{3} 19$ with $\mathrm{Bgl} 2$ and HindIII and ligating the resulting small fragment with the large fragment obtained from the digestion of $K S / E P_{3 A}$ with the same enzymes. The pBluescript clone of $\mathrm{EP}_{3} 11.2$ was digested with BamHI and the resulting small fragment was ligated to the large fragment obtained from the digestion of KS/EPS with BamHI to yield $\mathrm{KS} / \mathrm{EP}_{3 \mathrm{D}}$.

\section{Functional expression}

The $\mathrm{KS} / \mathrm{EP}_{3 \mathrm{~A}}$ clone was digested with SspI which cleaved it 2 bases upstream of nt 1 and again at nt 1421. The digest was electrophoresed on a $1 \%$ agarose gel and the $1.4 \mathrm{~kb}$ fragment was cut out and purified with Geneclean (Biol01). The eukaryotic expression vector, pBC12BI (Cullen, 1987), was digested with HindIII and BamHI, was blunt-ended with Klenow, and was electrophoresed on a $1 \%$ low-melting-point agarose gel. The $3.9 \mathrm{~kb}$ fragment was isolated and was used in a solid phase ligation with the $1.4 \mathrm{~kb}$ SspI fragment from $\mathrm{KS} / \mathrm{EP}_{3 \mathrm{~A}}$. Cells were transformed and a clone was obtained $\left(\mathrm{pBC} / \mathrm{EP}_{3 \mathrm{~A}}\right)$.

The $\mathrm{KS} / \mathrm{EP}_{3 \mathrm{E}}$ clone was used to prepare $\mathrm{pBC} / \mathrm{EP}_{3 \mathrm{E}}$ by digesting $\mathrm{pBC1} 2 \mathrm{BI}$ with HindIII and $\mathrm{BamHI}$, blunting, and ligating the large fragment to the blunt-ended $1.2 \mathrm{~kb}$ fragment obtained from digestion of $K S / E P_{3 E}$ with SspI and HinfI. $\mathrm{pBC} / \mathrm{EP}_{3 \mathrm{D}}$ was made by digesting $\mathrm{KS} / \mathrm{EP}_{3 \mathrm{D}}$ with HindIII and SspI and ligating the coding fragment to the large fragment obtained from $\mathrm{pBC} 12 \mathrm{BI}$ which had been cleaved with BamHI, blunt-ended, and then cleaved with HindIII.

Functional expression was determined as previously described (Pepperl \& Regan, 1993) in a transient assay using JEG-3 cells and an adenosine $3^{\prime}: 5^{\prime}$-cyclic monophosphate (cyclic AMP)-responsive chloramphenicol acetyl transferase reporter gene (CRE-CAT). Briefly, JEG-3 cells were cotransfected with DNA encoding $\mathrm{pBC} / \mathrm{EP}_{3}$ receptor variants and the reporter gene using calcium phosphate precipitation. The cells were maintained in DMEM/5\% FBS for $36-40 \mathrm{~h}$ and were then rinsed twice with DMEM and drugs were added. They were incubated for $4 \mathrm{~h}$ at $37^{\circ} \mathrm{C}$ and were harvested. CAT assays were done using $50 \mu \mathrm{l}$ cytosol, $200 \mathrm{nCi}\left[{ }^{3} \mathrm{H}\right]-$ chloramphenicol and $300 \mu \mathrm{M}$ butyryl CoA. The butyrylated chloramphenicol was extracted into xylenes and the radiolabelled product was measured by liquid scintillation counting.

\section{Radioligand binding}

COS-7 cells were transfected as previously described (Regan et al., 1988) with the $\mathrm{pBC} / \mathrm{EP}_{3}$ receptor constructs. Three days later the cells were harvested and membranes were prepared by homogenization and differential centrifugation. Membranes were resuspended in $50 \mathrm{mM}$ Tris- $\mathrm{HCl} / 10 \mathrm{mM}$ $\mathrm{MgCl}_{2} / 1 \mathrm{mM}$ EDTA/pH 7.4 at a concentration of $\sim 1 \mathrm{mg}$ $\mathrm{ml}^{-1}$ and were frozen at $-80^{\circ} \mathrm{C}$. The membranes were thawed, diluted with ice-cold $50 \mathrm{mM}$ Tris $\mathrm{HCl} / \mathrm{pH} 7.4$ (TB), and were dispersed with sonication. Binding was determined in triplicate in a final volume of $200 \mu \mathrm{l}$ for $30 \mathrm{~min}$ at $25^{\circ} \mathrm{C}$. Non-specific binding was defined with $10 \mu \mathrm{M} \mathrm{PGE}_{2}$. Reactions were started by the addition of membranes and were terminated by the addition of $4 \mathrm{ml}$ of ice-cold TB followed by rapid filtration through Whatman GF/B filters and 3 additional $4 \mathrm{ml}$ washes with a cell harvester (Brandel). The filters were dried, placed in $5 \mathrm{ml}$ of scintillation fluid (Ready Protein, Beckman), and counted (Beckman LS-380). Competition studies were done with a final concentration of $5 \mathrm{nM}$ $\left[{ }^{3} \mathrm{H}\right]-\mathrm{PGE}_{2}$. Data were analyzed by computer using the EBDA/Ligand programme (McPherson, 1985).

\section{Northern blot analysis}

Preparation of human polyA ${ }^{+}-\mathrm{RNA}$, electrophoresis and transfer to a nylon membrane was done by the manufacturer (Clontech, Multiple Tissue Northern, catalogue No. 7760-1). Accordingly, polyA ${ }^{+}-$RNA was prepared by oligo(dT) cellulose chromatography and electrophoresis was on $1.2 \%$ agarose/formaldehyde gels. Probes were radiolabelled with ${ }^{32} \mathrm{P}-\mathrm{dCTP}$ by nick translation (Gibco/BRL) and were purified by size exclusion chromatography (Chromaspin-10, Clontech). Prehybridization was in $10 \mathrm{ml}$ of $44 \%$ formamide/ $8.8 \times$ Denhardt's $/ 88 \mu \mathrm{g} \mathrm{ml}^{-1}$ herring sperm DNA $/ 4.4 \times \mathrm{SSPE} /$ $1.8 \%$ SDS for $3 \mathrm{~h}$ at $42^{\circ} \mathrm{C}$. Hybridization was for $\sim 16 \mathrm{~h}$ at $42^{\circ} \mathrm{C}$ in $8 \mathrm{ml}$ of the prehybridization buffer containing $\sim 1.5 \times 10^{6}$ c.p.m. $\mathrm{ml}^{-1}$ of probe. Blots were rinsed $6 \times 5 \mathrm{~min}$ at $24^{\circ} \mathrm{C}$ in $2 \times \mathrm{SSC} / 0.5 \% \mathrm{SDS}$ and then $2 \times 20 \mathrm{~min}$ at $50^{\circ} \mathrm{C}$ in $0.1 \times \mathrm{SSC} / 0.1 \%$ SDS. Exposures were made at $-80^{\circ} \mathrm{C}$ using Kodak AR film.

\section{PCR analysis of variant expression}

Sense and antisense primers corresponding to TM5 and the 3'-untranslated regions, respectively, of the human $\mathrm{EP}_{3}$ receptor variants were used in $\mathrm{RT} / \mathrm{PCR}$ reactions to confirm the expression of the variants in total RNA from human tissues. The sense primer represents nt's 774-791 (Figure 1) which is common to all of the variants. The antisense primers are as follows: $\mathrm{EP}_{3 \mathrm{~A}}$, nt's 1257-1274; $\mathrm{EP}_{3 \mathrm{Al}}$, nt's 1356-1373; $\mathrm{EP}_{3 \mathrm{E}}$, nt's 1164-1181; $E_{3 \mathrm{D}}$, nt's 1166-1183 (Figure 2). The reverse transcription reaction (final volume, $60 \mu \mathrm{l}$ ) contained $6 \mu \mathrm{l}$ $10 \times$ PCR buffer (Boehringer Mannheim), $2 \mu \mathrm{l}$ RNasin, $6 \mu \mathrm{l}$ dNTP's $(10 \mathrm{mM}), 6 \mu \mathrm{l}$ random primers (6-mers, $0.04 \mathrm{~A}_{260}$, $\left.\mu 1^{-1}\right)$ or $6 \mu \mathrm{l}(\mathrm{dT})_{15}\left(0.02 \mathrm{~A}_{260} \mu \mathrm{l}^{-1}\right), 2 \mu \mathrm{l}$ denatured $\left(65^{\circ} \mathrm{C}\right.$ for $10 \mathrm{~min}) \mathrm{RNA}\left(1 \mu \mathrm{g} \mathrm{ul}^{-1}\right), 12 \mu \mathrm{l} \mathrm{MgCl} 2(25 \mathrm{mM}), 0.6 \mu \mathrm{l}$ acetylated BSA $\left(10 \mathrm{mg} \mathrm{ml}^{-1}\right)$ and $7 \mu \mathrm{l} \mathrm{AMV} \mathrm{reverse} \mathrm{transcriptase.}$ The reaction was incubated at room temperature $\left(\sim 24^{\circ} \mathrm{C}\right)$ for $10 \mathrm{~min}, 42^{\circ} \mathrm{C}$ for $45 \mathrm{~min}, 95^{\circ} \mathrm{C}$ for $5 \mathrm{~min}$ and was placed on ice. The PCR reaction (final volume, $50 \mu \mathrm{l}$ ) contained $4 \mu \mathrm{l}$ from the reverse transcription reaction, $5 \mu 110 \times$ PCR buffer, $0.6 \mu \mathrm{l}$ sense primer $(25 \mu \mathrm{M}), 0.6 \mu \mathrm{l}$ antisense primer $(25 \mu \mathrm{M})$, $3 \mu \mathrm{l} \mathrm{MgCl}_{2}, 2 \mu \mathrm{l}$ dNTP's $(1.25 \mathrm{mM}), 1 \mu$ l tetra-methyl-ammonium chloride $(2.5 \mathrm{mM}$ ) and $0.3 \mu \mathrm{l}$ Taq polymerase (Perkin Elmer, $\left.5 \mathrm{u} \mu \mathrm{l}^{-1}\right)$. An initial denaturation step at $94^{\circ} \mathrm{C}$ for $2 \mathrm{~min}$ was followed by 35 cycles of $94^{\circ} \mathrm{C}, 15 \mathrm{~s} ; 60^{\circ} \mathrm{C}, 15 \mathrm{~s}$; $72^{\circ} \mathrm{C}, 36 \mathrm{~s}$ and a final step at $72^{\circ} \mathrm{C}$ for $6 \mathrm{~min}$. Products were analyzed by agarose gel $(1.5 \%)$ electrophoresis followed by staining with ethidium bromide.

\section{Results}

Using the polymerase chain reaction (PCR) and primers designed from the first extracellular loop and sixth transmembrane (TM) domain of the mouse $\mathrm{EP}_{3}$ prostaglandin receptor (Sugimoto et al., 1992), a product of $\sim 500$ base 
pairs was obtained from human small intestine RNA. Analysis of the product's nucleotide and deduced amino acid sequence indicated that it was the human homologue of the mouse $\mathrm{EP}_{3}$ receptor. The PCR product was labelled with ${ }^{32} \mathrm{P}$ and was used to screen a human genomic library by plaque hybridization analysis. A clone was isolated and was found to contain nucleotide sequence identical to the PCR product, however, downstream of nt 953 (Figure 1) the sequence of the genomic clone diverged radically from the mouse $\mathbf{E P}_{3}$ receptor sequence. This divergence, which in the deduced amino acid sequence corresponds to TM6, marks the beginning of an intron. Subsequent Southern blot analysis of the genomic clone with a probe encoding TM7 from the human $\mathrm{EP}_{3 \mathrm{~A}}$ receptor cDNA was negative, indicating that the downstream exon(s) were not present in this clone.

The ${ }^{32} \mathrm{P}$-labelled PCR product was then used to screen a human small intestine cDNA library. A total of 7 clones were isolated and sequenced. One of these clones appeared to correspond to the mouse $\mathrm{EP}_{3 \alpha}$ (Sugimoto et al., 1993) but it lacked some of the $5^{\prime}$ coding region. Between it and the genomic clone, a full length clone encoding the human $\mathrm{EP}_{3 \mathrm{~A}}$ was constructed. Later, two of the other cDNA clones were found to have complete $5^{\prime}$ coding sequences which confirmed the sequence of the recombinant receptor. The complete nucleotide and deduced amino acid sequence of the human $\mathbf{E P}_{3 \mathrm{~A}}$ clone is shown in Figure 1. The overall amino acid identity of this clone with the mouse $\mathrm{EP}_{3 \alpha}$ sequence is $79 \%$ and identity in the transmembrane domains is $91 \%$. Like the mouse sequence, the human $\mathbf{E P}_{3 \mathrm{~A}}$ has a short third intracellular loop ( $\sim 26$ amino acids), two consensus sites for $\mathrm{N}$-linked glycosylation in the amino terminus and an aspartate residue in TM7 that is conserved in other prostanoid receptors but is an asparagine in other G-protein coupled receptors.

Among the other cDNA clones was one $\left(\mathrm{EP}_{3 \mathrm{Al}}\right)$ that had a coding sequence identical to the $\mathbf{E P}_{3 \mathrm{~A}}$ but which had a completely different $3^{\prime}$ untranslated sequence beginning in the

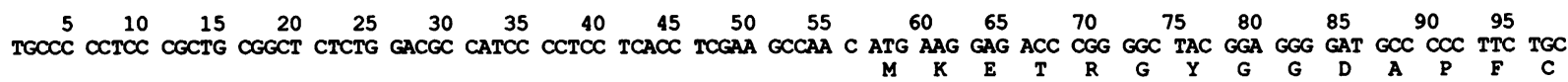

$\begin{array}{llllllllllllllllllllll}100 & 105 & 110 & 115 & 120 & 125 & 130 & 135 & 140 & 145 & 150 & 155 & 160 & 165 & 170 & 175 & 180 & 185 & 190\end{array}$

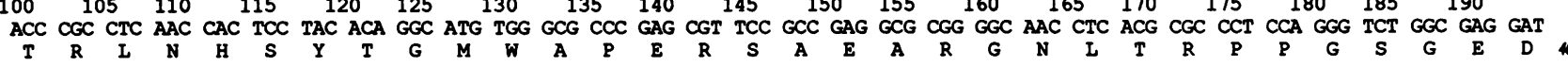

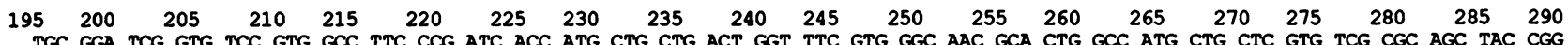

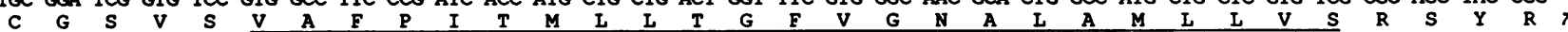

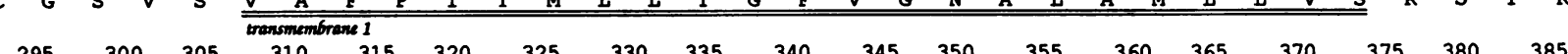

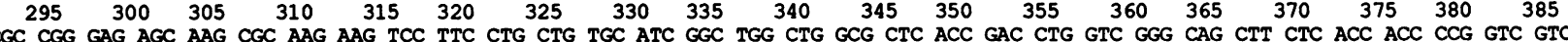

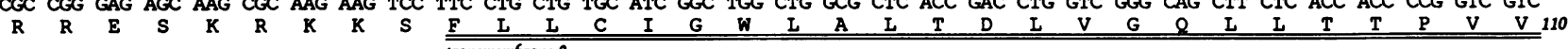
$\begin{array}{llllllllllllllllllllll}390 & 395 & 400 & 405 & 410 & 415 & 420 & 425 & 430 & 435 & 440 & 445 & 450 & 455 & 460 & 465 & 470 & 475 & 480\end{array}$ ATC GTC GTG TAC CTG TCC AAG CAG CGT TGG GAG CAC ATC GAC CCG TCG GGG CGG CTC TGC ACC TTT TTC GGG CTG ACC ATG ACT GTT TTC GGG CTC

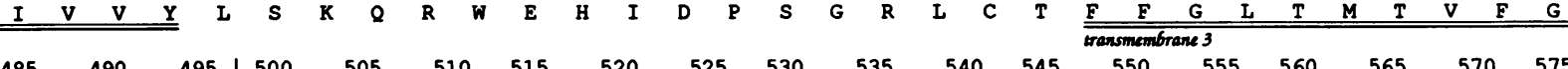

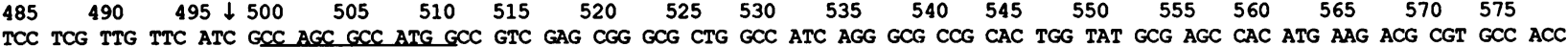

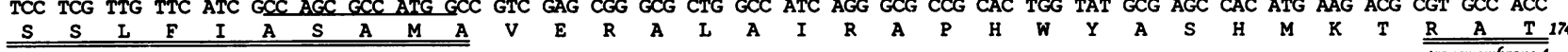

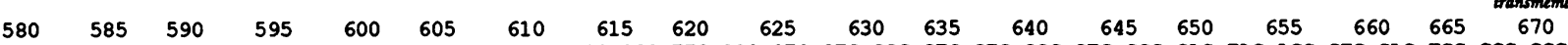
CGC GCT GTG CTG CTC GGC GTG TGG CTG GCC GTG CTC GCC TTC GCC CTG CTG CCG GTG CTG GGC GTG GGC CAG TAC ACC GTC CAG TGG CCC GGG ACG

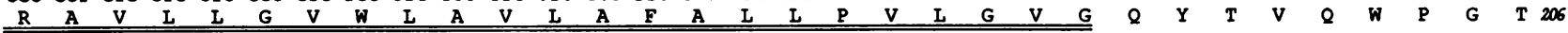
$\begin{array}{llllllllllllllllllll}675 & 680 & 685 & 690 & 695 & 700 & 705 & 710 & 715 & 720 & 725 & 730 & 735 & 740 & 745 & 750 & 755 & 760 & 765 & 770\end{array}$ TGG TGC TTC ATC AGC ACC GGG CGA GGG GGC AAC GGG ACT AGC TCT TCG CAT AAC TGG GGC AAC CTT TTC TTC GCC TCT GCC TTT GCC TTC CTG GGG

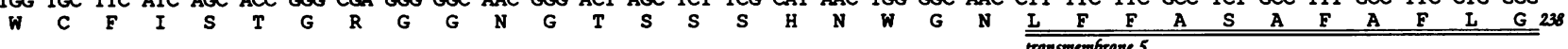

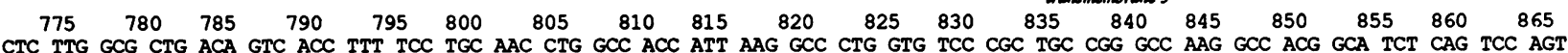

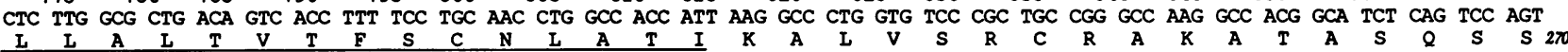

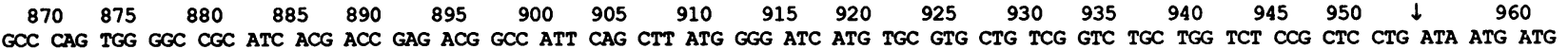

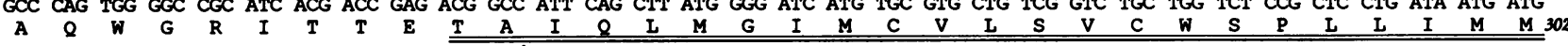
$\begin{array}{lllllllllllllllllll}965 & 970 & 975 & 980 & 985 & 990 & 995 & 1000 & 1005 & 1010 & 1015 & 1020 & 1025 & 1030 & 1035 & 1040 & 1045 & 1050 & 1055\end{array}$ TTG AAA ATG ATC TTC AAT CAG ACA TCA GTT GAG CAC TGC AAG ACA CAC ACG GAG AAG CAG AAA GAA TGC AAC TTC TTC TTA ATA GCT GTT CGC CTG

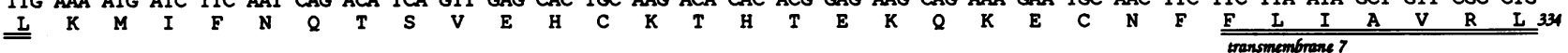

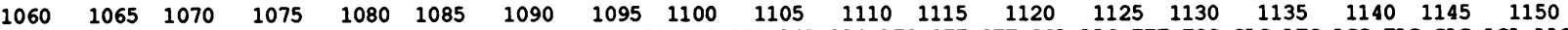
GCT TCA CTG AAC CAG ATC TTG GAT CCT TGG GTT TAC CTG CTG TTA AGA AAG ATC CTT CTT CGA AAG TTT TGC CAG ATC AGG TAC CAC ACA AAC AAC

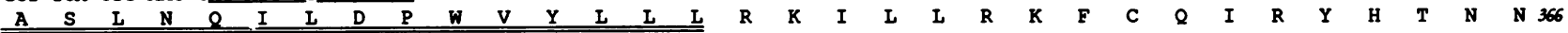

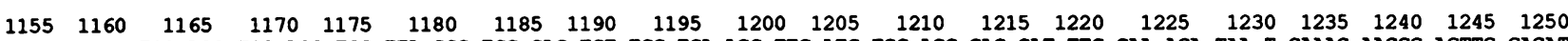
TAT GCA TCC AGC TCC ACC TCC TTA CCC TGC CAG TGT TCC TCA ACC TTG ATG TGG AGC GAC CAT TTG GAA AGA TAA T GAAAG AACGG AGTTG GACA

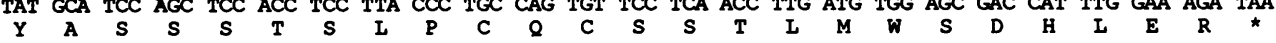

\begin{tabular}{|c|c|c|c|c|c|c|c|c|c|c|c|c|c|c|c|c|c|c|c|}
\hline & 1260 & & 1270 & & 1280 & & 1290 & & 1300 & & 1310 & & 1320 & & 1330 & & 1340 & & 1350 \\
\hline TTTAT & TGCAA & TTCCT & GCTTC & CCTGA & ATTTG & CATAT & TTCTT & CCCAC & CTGAG & AAGGA & TAATT & ATATA & TTTTA & ATTTG & GATTA & TTTCT & TCATT & TTTAT & СтTTT \\
\hline & 1360 & & 1370 & & 1380 & & 1390 & & 1400 & & 1410 & & 1420 & & 1430 & & 1440 & & 1450 \\
\hline TATTT & TAATG & ATTGT & TTTGT & CAGTA & ATACC & CATGG & AGATC & AACTT & TATTA & TTATA & ATCCA & TGCCT & CTGAA & TATTA & GATTG & GTTTC & TTGGA & TGGGA & TTTTG \\
\hline & 1460 & & 1470 & & 1480 & & 1490 & & 1500 & & 1510 & & 1520 & & 1530 & & 1540 & & 1550 \\
\hline ATATG & САTTT & GAA & GTTGG & GAAGA & ATTTC & ACAGA & TGATG & ATTGG & AGGAA & AAGTG & ATGAA & AAGAA & GACCT & GTGTT & CCAGG & AGT & тстсC & AACTT & CAAAC \\
\hline & 1560 & & 1570 & & 1580 & & 1590 & & 1600 & & 1610 & & 1620 & & 1630 & & 1640 & & 1650 \\
\hline TT & $\begin{array}{r}\text { CGTGA } \\
1660\end{array}$ & TT & $\begin{array}{r}\text { AACCA } \\
1670\end{array}$ & AAGTG & $\begin{array}{r}\text { ACATC } \\
1680\end{array}$ & TTTAC & $\begin{array}{r}\text { ATTTC } \\
1690\end{array}$ & rGAT & $\begin{array}{r}\text { AGCTT } \\
1700\end{array}$ & ETTI & $\begin{array}{r}\text { TGCAA } \\
1710\end{array}$ & TGA & $\begin{array}{r}\text { GTTTG } \\
1720\end{array}$ & AAAA & TCANG & ATAA & STAT & A? & TGAAA \\
\hline
\end{tabular}

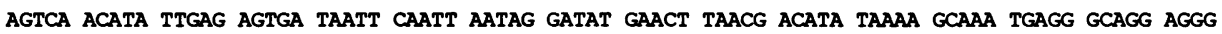

Figure 1 Nucleotide (nt) and deduced amino acid sequence of the human $\mathbf{E P}_{3 \mathrm{~A}}$ receptor. The coding sequence is from nt's 57 to 1226 and the 390 amino acid sequence is indicated using the single letter code. Putative transmembrane regions are indicated by the double underline. The beginning of cDNA clone $\mathrm{EP}_{3} 27$ is indicated by the arrow $(\downarrow)$ at nt 497 . The beginning of an intron in the genomic sequence is indicated by the arrow $(\downarrow)$ after nt 953 . The single underlines are restriction enzymes sites that were used in making recombinants: they are as follows, BstXI, nt's 499-510; Bgl2, nt's 1072-1077; BamHI, nt's 1079-1084; and SspI nt's $1419-1424$. 
stop codon at nt 1227. The nucleotide and deduced amino acid sequence of this and 2 other variants are shown in Figure 2. The other 2 variants, $\mathbf{E P}_{3 \mathrm{E}}$ and $\mathrm{EP}_{3 \mathrm{D}}$, share the same nucleotide sequence as the $\mathrm{EP}_{3 \mathrm{~A}}$ up to $\mathrm{nt} 1133$ but then they diverge from each other and from the $E_{3 A}$. With respect to their amino acid sequences, this gives rise to 3 possible carboxyl terminal variants of the human $\mathrm{EP}_{3}$ receptor. Assuming that ${ }^{350} \mathrm{R}$ marks the beginning, the carboxyl terminus of the $\mathrm{EP}_{3 \mathrm{~A}}$ would consist of 41 amino acids, while the $\mathrm{EP}_{3 \mathrm{E}}$ and $\mathrm{EP}_{3 \mathrm{D}}$ would consist of 16 and 39 amino acids, respectively. There is no amino acid identity between the variants in these regions nor is there any nucleotide sequence

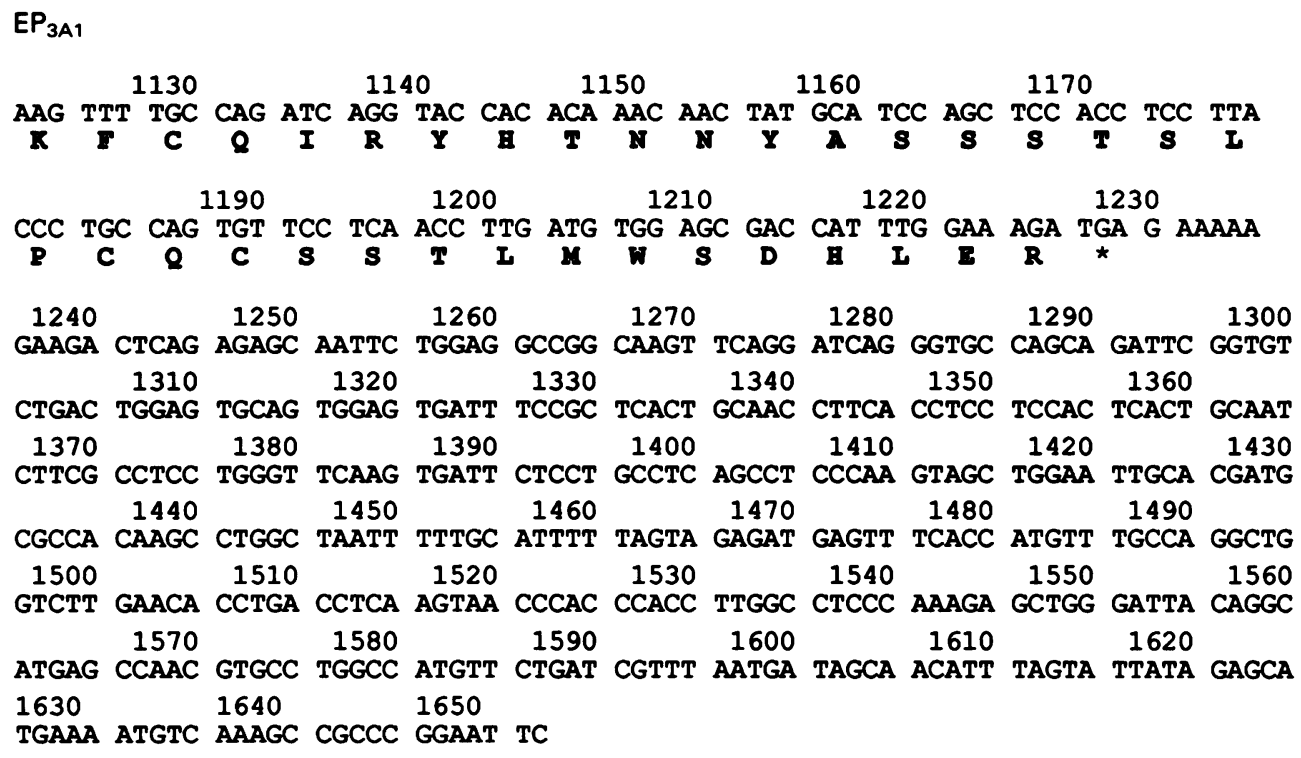

$E P_{3 D}$ $1130 \quad 1140 \quad 1150 \quad 1160 \quad 1170$

Figure 2 Nucleotide and deduced amino acid sequences of the human $\mathrm{EP}_{3}$ receptor variants in their carboxyl termini and 3'-untranslated regions. From top to bottom: the $\mathrm{EP}_{3 \mathrm{Al}}$, the $\mathrm{EP}_{3 \mathrm{E}}$ and the $\mathrm{EP}_{3 \mathrm{D}}$. Sequences start with nt 1122 (aa. No 356) with upstream sequences the same as in Figure 1 for the $\mathrm{EP}_{3 \mathrm{~A}}$. Amino acid sequences that overlap with the $\mathbf{E P}_{3 \mathrm{~A}}$ are in bold type face. The single underlines from nt's 1196-1200 in the $\mathrm{EP}_{3 \mathrm{E}}$ and nt's 1530-1535 in the $\mathrm{EP}_{3 \mathrm{D}}$ are HinfI and SspI sites, respectively, that were used in making recombinants. 

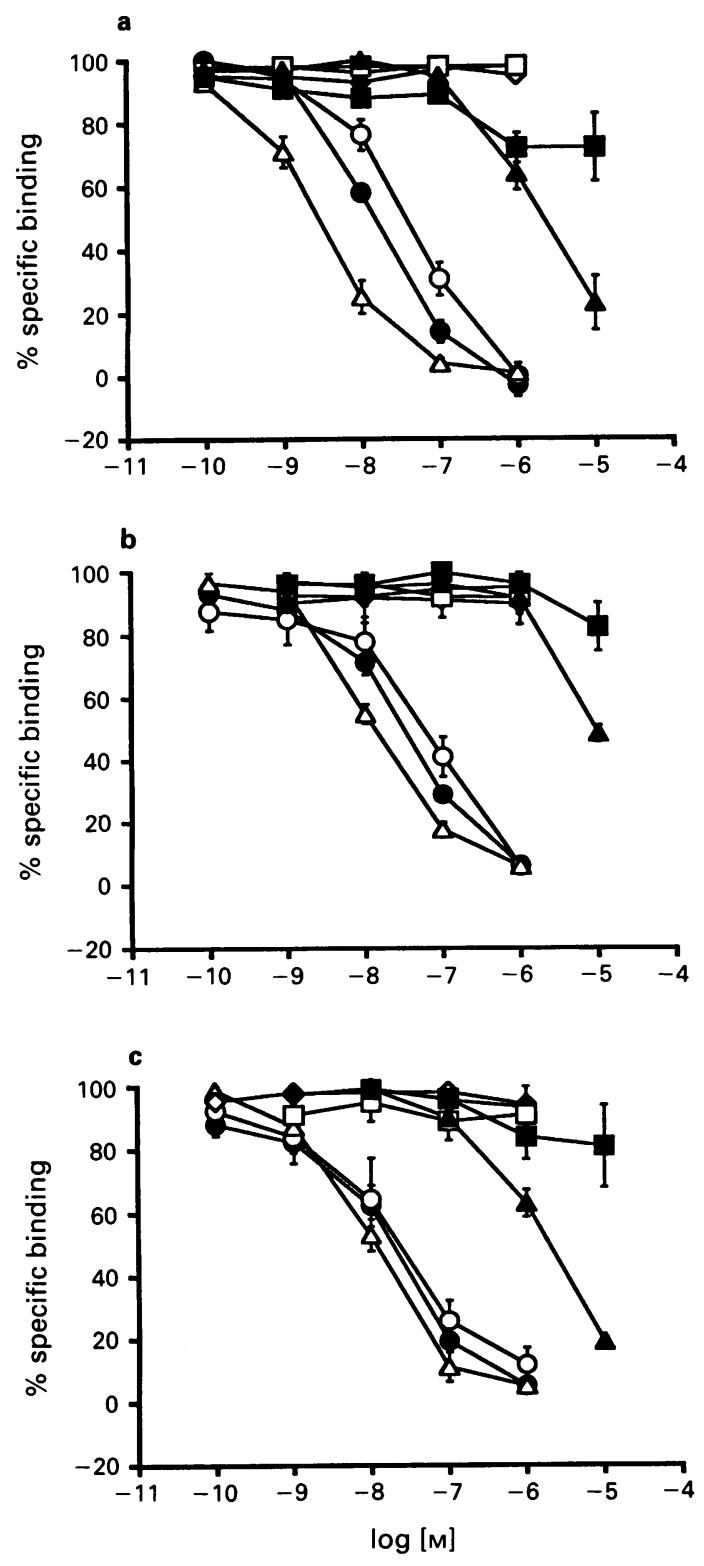

Figure 3 Inhibition of specific $\left[{ }^{3} \mathrm{H}\right]-\mathrm{PGE}_{2}$ binding to membranes prepared from COS-7 cells that have been transfected with plasmid DNA encoding the three human $\mathrm{EP}_{3}$ receptor variants. Competitors include natural prostaglandins and compounds that are selective for the various prostaglandin receptor subtypes and are as follows: PGE $_{2}$

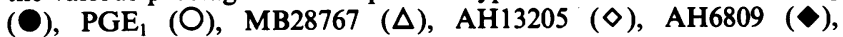
U46619 (口), $\mathrm{PGF}_{2 \alpha}(\Delta), \mathrm{PGD}_{2}$ (ם). (a) $\mathrm{EP}_{3 \mathrm{~A}}$; (b) $\mathrm{EP}_{3 \mathrm{D}}$; (c) $\mathrm{EP}_{3 \mathrm{E}}$. Binding was done as described in Methods with a final concentration of $5 \mathrm{nM}\left[{ }^{3} \mathrm{H}\right]-\mathrm{PGE}_{2}$. Data represent the means \pm s.e.mean from three separate experiments, each performed in triplicate.

Table 1 Competition for the binding of $\left[{ }^{3} \mathrm{H}\right]$-prostaglandin $\left.E_{2}\left({ }^{3} \mathrm{H}\right]-\mathrm{PGE}_{2}\right)$ to membranes prepared from COS-7 cells transfected with plasmid DNA encoding alternative splicing variants of the human $\mathrm{EP}_{3}$ prostaglandin receptor ${ }^{1}$

\begin{tabular}{|c|c|c|c|}
\hline \multirow[b]{2}{*}{ Competitor } & \multicolumn{3}{|c|}{ Receptor variants $\left(\mathrm{IC}_{50}\right.$ in $\left.\mathrm{nM}\right)$} \\
\hline & $E P_{3 A}$ & $E P_{3 D}$ & $E P_{3 E}$ \\
\hline MB28767 & 3 & 14 & 16 \\
\hline $\mathrm{PGE}_{2}$ & 15 & 32 & \\
\hline $\mathrm{PGE}_{1}$ & 39 & 60 & 25 \\
\hline $\mathrm{PGF}_{2 \alpha}$ & 2300 & 9300 & 1200 \\
\hline
\end{tabular}

${ }^{1}{ }^{I} C_{50}$ 's were calculated from the data shown in Figure 3 and represent the pooled data from 3 separate experiments. $K_{d} \mathrm{~s}$ for the equilibrium saturation binding of $\left[{ }^{3} \mathrm{H}\right]-\mathrm{PGE}_{2}$ were: 1 , 8 and $6 \mathrm{nM}$ for the $\mathrm{EP}_{3 \mathrm{~A}}, \mathrm{EP}_{3 \mathrm{D}}$, and $\mathrm{EP}_{3 \mathrm{E}}$, respectively. identity. This is in contrast to the mouse $\mathrm{EP}_{3}$ receptor variants which differ from one another because of a deletion and frame-shift (Sugimoto et al., 1993).

The $\mathrm{EP}_{3}$ receptor variants were cloned into a mammalian expression vector and were expressed transiently in COS-7 cells. Membranes were prepared and radioligand binding was determined using $\left[{ }^{3} \mathrm{H}\right]-\mathrm{PGE}_{2}$. Figure 3 shows the results of competition studies using compounds predicted to have varying degrees of affinity for the $\mathrm{EP}_{3}$ receptor. $\mathrm{PGE}_{2}, \mathrm{PGE}_{1}$, and MB28767 ( $\mathrm{EP}_{3}$ selective) all potently inhibited [ $\left.{ }^{3} \mathrm{H}\right]-\mathrm{PGE}_{2}$ binding; the rank order of potency for all the variants being MB28767 $>$ PGE $_{2}>$ PGE $_{1}$. There were, however, differences between the variants in the $\mathrm{IC}_{50} \mathrm{~s}$ for some of the competitors (Table 1). For example, a 13 fold difference separated the $\mathrm{IC}_{50} \mathrm{~S}$ of $\mathrm{MB} 28767$ and $\mathrm{PGE}_{1}$ at the $\mathrm{EP}_{3 \mathrm{~A}}$, whereas, only a 2 fold difference separated them at the $\mathrm{EP}_{3 \mathrm{E}}$. Most of this difference could be accounted for by a higher affinity of MB28767 for the $\mathrm{EP}_{3 \mathrm{~A}}$. $\mathrm{PGF}_{2 \alpha}$ also seemed to discriminate between the variants to some extent, showing higher affinity for the $\mathrm{EP}_{3 \mathrm{~A}}$ and $\mathrm{EP}_{3 \mathrm{E}}$ as compared with the $\mathrm{EP}_{3 \mathrm{D}}$. The other compounds competed very poorly or not at all. These included the selective thromboxane receptor agonist, U46619, the $\mathrm{EP}_{1}$ selective antagonist, $\mathrm{AH} 6809$, the $\mathrm{EP}_{2}$ selective agonist $\mathrm{AH} 13205$, and $\mathrm{PGD}_{2}$.

The $\mathrm{EP}_{3}$ receptor variants were also co-transfected into JEG-3 cells with a cyclic AMP responsive-chloramphenicol acetyltransferase reporter plasmid (CRE-CAT). This plasmid responds to changes in intracellular cyclic AMP and has been developed into a transient functional assay for receptors that interact with adenylyl cyclase (Pepperl \& Regan, 1993). Figure 4 shows the inhibition of forskolin-stimulated CAT activity by sulprostone for the $\mathrm{EP}_{3 \mathrm{~A}}, \mathrm{EP}_{3 \mathrm{D}}$ and $\mathrm{EP}_{3 \mathrm{E}}$ receptor variants. The curves are biphasic with an inhibition of CAT activity occurring at low concentrations of sulprostone and a reversal at higher concentrations. A similar type of doseresponse pattern has also been observed for $\alpha_{2}$-adrenoceptor subtypes (Pepperl \& Regan, 1993) and for muscarinic receptors (Jones et al., 1991) using both this assay and/or direct measurements of cyclic AMP. Figure 4 also shows that the $\mathrm{EP}_{3 \mathrm{~A}}$ inhibited forskolin-stimulated CAT activity to a greater extent than either the $\mathrm{EP}_{3 \mathrm{D}}$ or $\mathrm{EP}_{3 \mathrm{E}}$. With respect to the potency of sulprostone, large differences were not observed between the variants, although, there was a tendency for sulprostone to have a lower $\mathrm{EC}_{50}$ at the $\mathrm{EP}_{3 \mathrm{~A}}$.

The full coding sequence of the human $\mathrm{EP}_{3 \mathrm{~A}}$ was radiolabelled with ${ }^{32} \mathrm{P}$ by nick-translation and was used as a probe in Northern blot analyses to examine the distribution of $\mathrm{EP}_{3}$ receptor message in several human tissues. Figure 5 shows that mRNA from human kidney hybridized strongly with the probe. The most abundant message size was $\sim 2.4 \mathrm{~kb}$ but other bands at 5.1 and $7 \mathrm{~kb}$ were also observed. Longer exposures revealed a small amount of the $2.4 \mathrm{~kb}$ message in mRNA from the pancreas and heart.

The polymerase chain reaction (PCR) was used with primer combinations that were specific for each of the cDNA variants of the $\mathrm{EP}_{3}$ receptor to determine if human tissues contained mRNA that corresponded to these variants. Figure 6 shows that using human small intestine RNA and reverse transcription followed by PCR, products were obtained that represented each of the cloned $\mathrm{EP}_{3}$ receptor variants. Similar results were obtained with RNA from the human heart and pancreas except that only a single band was observed with primers that were specific for the $\mathrm{EP}_{3 \mathrm{E}}$.

\section{Discussion}

A human small intestine cDNA library was screened with a PCR product encoding a portion of a human $\mathrm{EP}_{3}$ receptor and 4 unique cDNA variants of this receptor were identified. One of these variants, the human $\mathrm{EP}_{3 \mathrm{~A}}$ appears to be the homologue of the mouse $\mathrm{EP}_{3 \alpha}$ (Sugimoto et al., 1993). A second variant $\left(\mathrm{EP}_{3 \mathrm{~A} 1}\right)$ contains the same coding sequence as 

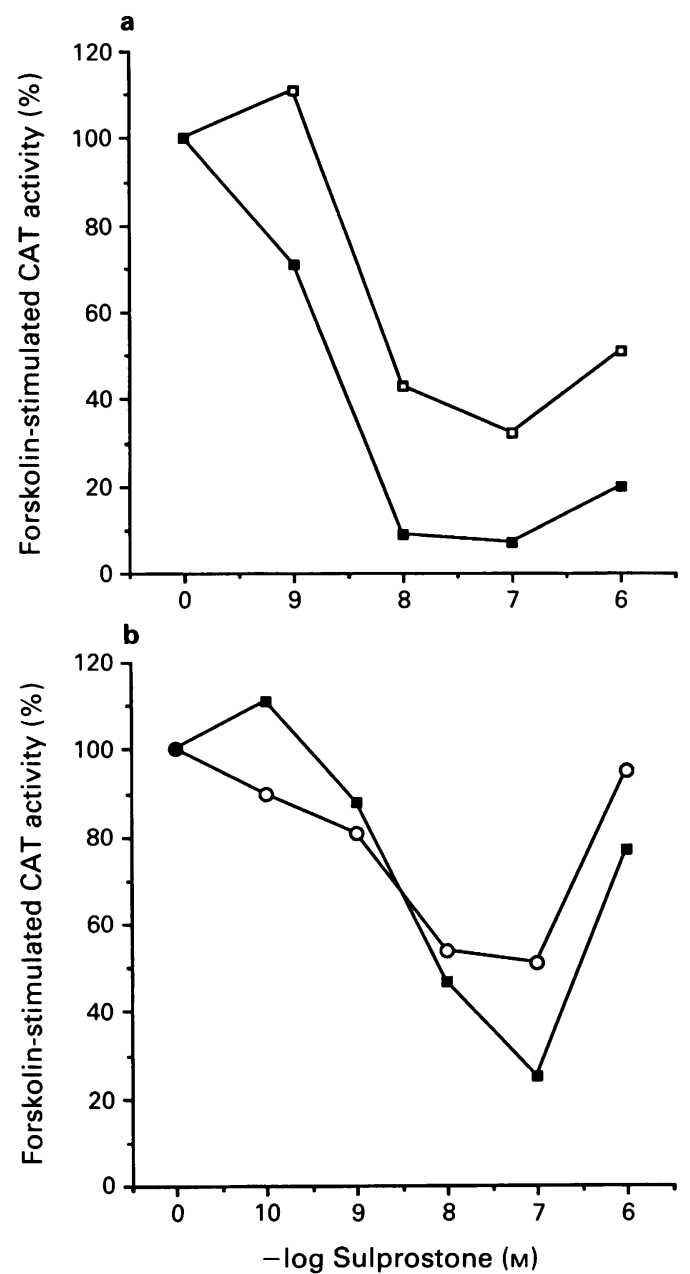

Figure 4 Effects of sulprostone on forskolin-stimulated CRE-CAT reporter gene activity after transient transfection of JEG-3 cells with DNA encoding either: (a) the $\mathrm{EP}_{3 \mathrm{~A}}(\boldsymbol{\square})$ and $\mathrm{EP}_{3 \mathrm{D}}(\square)$; or (b) the $\mathrm{EP}_{3 \mathrm{~A}}(\square)$ and $\mathrm{EP}_{3 \mathrm{E}}(\mathrm{O})$. Each curve is expressed as a percentage of the forskolin-stimulated activity in the absence of sulprostone. Transfections and CAT assays were done as described in Methods. Forskolin was used at a final concentration of $1 \mu \mathrm{M}$. For (a) data are representative of 2 experiments and for (b) data are representative of 4 experiments.

the $\mathrm{EP}_{3 \mathrm{~A}}$ but has a completely divergent $3^{\prime}$ untranslated region beginning with the stop codon. The last two variants, the human $E_{3 E}$ and $E P_{3 D}$, encode receptors with the same amino acid sequence as the $\mathrm{EP}_{3 \mathrm{~A}}$ except for their predicted carboxyl terminal domains. These carboxyl terminal sequence differences appear to affect some of the ligand binding properties of these variants and their functional coupling to a cyclic AMP responsive reporter gene. In addition, since the $3^{\prime}$-untranslated region can affect mRNA stability, the existence of $\mathrm{EP}_{3}$ receptor variants with alternative $3^{\prime}$ untranslated sequences may also be important for regulating the expression of these receptors.

It is interesting that nucleotide sequences of the human $E_{3 E}$ and $E_{3 D}$ diverge from each other and from the $E_{3 A}$ at exactly the same point (nt 1133, Figure 1); which is also where the mouse $\mathrm{EP}_{3 \beta}$ diverges from the $\mathrm{EP}_{3 \alpha}$ (Sugimoto et al., 1993). In the case of cDNAs encoding the mouse $\mathrm{EP}_{3}$ receptors, the origin of this divergence involves a deletion of 89 nucleotides which results in a frame shift that changes the sequence of the next 26 amino acids before a new termination codon is reached. For our human variants such a mechanism is not in evidence because the nucleotide sequences in the divergent regions do not share identity. In either case mRNA splicing involving exons encoding alternative car-

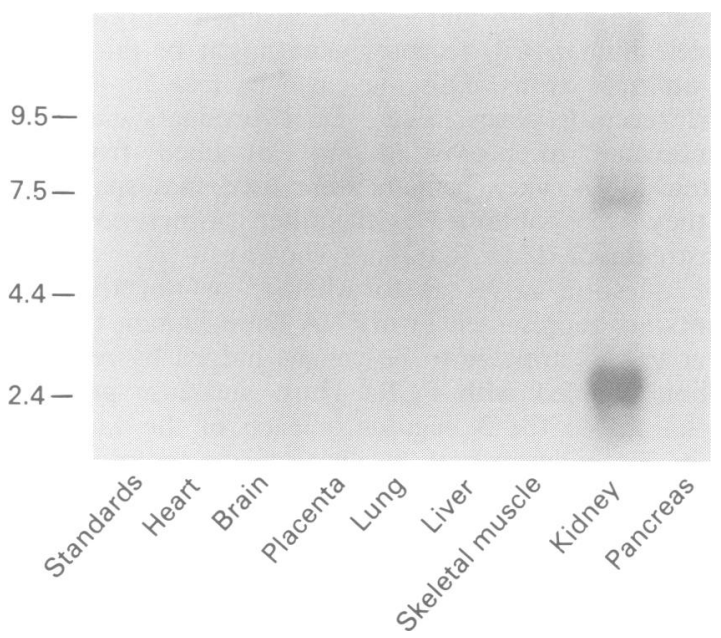

Figure 5 Northern Blot of human mRNA's hybridized with the full coding sequence (nt's -2 to 1421) of the human $\mathrm{EP}_{3 \mathrm{~A}}$ radiolabelled with ${ }^{32} \mathrm{P}$ by nick-translation. Hybridization, wash and exposure conditions are described in Methods. Lane 1, heart; lane 2, brain; lane 3, placenta; lane 4 , lung; lane 5 , liver; lane 6 , skeletal muscle; lane 7 , kidney; lane 8 , pancreas. The position of the size standards are indicated. The blot was stripped and probed with a $\beta$-actin probe that indicated that similar amounts of RNA were loaded in each lane.

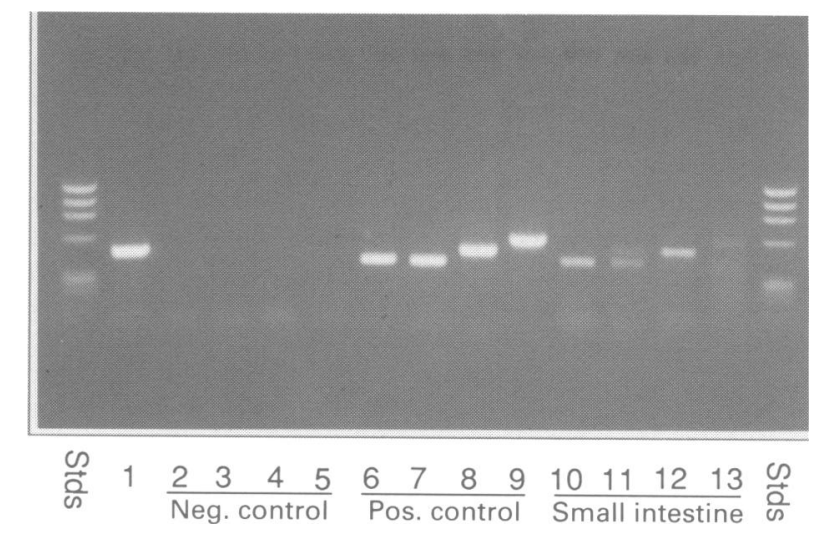

Figure 6 Photograph of ethidium-stained agarose gel of the products of a reverse transcription/PCR reaction with primers specific for each of the human $\mathrm{EP}_{3}$ receptor cDNA variants. Lane 1 is a positive control for the PCR reaction; lanes $2-5$ are negative controls (no templates); lanes 6-9 are positive controls using plasmid DNA encoding each of the human $\mathrm{EP}_{3}$ receptor variants; lanes $10-13$ are the results of the RT/PCR reaction using RNA from human small intestine. In each set of reactions (ie. negative control, positive control, small intestine), primers specific for the following variants were used $\mathrm{EP}_{3 \mathrm{~B}}, \mathrm{EP}_{3 \mathrm{E}}, \mathrm{EP}_{3 \mathrm{~A}}$ and $\mathrm{EP}_{3 \mathrm{~A}}$. The expected product sizes (bp) were as follows: $\mathrm{EP}_{3 \mathrm{D}}, 409 ; \mathrm{EP}_{3 \mathrm{E}}, 407$; $\mathrm{EP}_{3 \mathrm{~A}}, 500$; and $\mathrm{EP}_{3 \mathrm{Al}}$, 599. Standards (stds) are HaellI cleaved $\Phi \times 174$.

boxyl termini appears to be operational. The use of alternative splicing, as a mechanism of creating receptor heterogeneity, does not appear to be common among the G-protein coupled receptors but it has been described for rhodopsin and for the dopamine receptors. Thus, two variants of the $\mathrm{D}_{2}$-dopamine receptor are known in which the use of alternative splicing creates 'long' and 'short' forms of the receptor which differ in the lengths of their third intracellular loops (Giros et al., 1989; Monsma et al., 1989; Dal Toso et al., 1989). In addition, splice variants of the $D_{3}$-dopamine receptor have been described (Giros et al., 1991).

Besides the cDNAs encoding carboxyl terminal variants of the $\mathrm{EP}_{3}$ receptor we found evidence of an intron in the human $\mathrm{EP}_{3}$ receptor gene in a region corresponding to TM6. We did not, however, find any cDNA clones that were variants at this position. Considering that separate exons 
may encode TM1-6 and 7, respectively, it appears that the complete human $\mathrm{EP}_{3}$ receptor gene might be fairly complex with multiple exons. This may also be true for other prostanoid receptor genes. Thus, PCR products encoding the thromboxane receptor were not obtained from human genomic DNA when primers were used that spanned TM6 but they were obtained with other primer combinations downstream of TM6 (data not shown).

The question arises as to whether or not these cDNA variants are represented in mRNA from human tissues. The answer to this appears to be yes, as judged by reverse transcription coupled with PCR. Thus, antisense primers that were unique to the $3^{\prime}$ regions of each of the variants were used in combination with a sense primer common to all of the variants. Four PCR products, corresponding to each of the variants, were obtained using RNA from human small intestine, as well as with RNA from human heart and pancreas. With RNA from human small intestine, however, the primers specific for the $\mathrm{EP}_{3 \mathrm{E}}$ consistently yielded two products: one of expected size and another that was 50-100 nt longer. By analogy to the mouse $\mathrm{EP}_{3 \beta}$, which contains an 89 bp deletion relative to the mouse $\mathbf{E P}_{3 \alpha}$, it is possible that the human $E_{3 E}$ receptor represents a deletion of yet another human $\mathrm{EP}_{3}$ receptor variant. The finding that the larger of the two products was obtained only with RNA from small intestine and not with RNA from heart or pancreas, suggests that $\mathrm{EP}_{3}$ receptor variants may be uniquely expressed in tissues. Additional studies, however, will be needed to define the tissue specific expression of $\mathrm{EP}_{3}$ receptor variants.

Further evidence that the $\mathrm{EP}_{3}$ receptor cDNA clones encoded functional receptors was obtained by radioligand binding studies of the cloned receptors expressed in mammalian cells lacking endogenous $\mathrm{EP}_{3}$ receptors. Thus, expression of the human $\mathrm{EP}_{3}$ receptor variants in COS-7 cells followed by radioligand binding with $\left[{ }^{3} \mathrm{H}\right]-\mathrm{PGE}_{2}$ have established an $\mathrm{EP}_{3}$ pharmacology. $\mathrm{PGE}_{2}$ was found to bind with high affinity as did the $\mathrm{EP}_{3}$-selective agonist, $\mathrm{MB} 28767$. The $\mathrm{EP}_{2}$-selective agonist, $\mathrm{AH} 13205$, and the $\mathrm{EP}_{1}$ selective antagonist, AH6809, did not inhibit $\left[{ }^{3} \mathrm{H}\right]-\mathrm{PGE}_{2}$ binding which further confirms these receptors as $\mathrm{EP}_{3}$. The inhibitory potency of $\mathrm{PGF}_{2 \alpha}$ in the human variants was similar to that reported for the cloned murine $\mathrm{EP}_{3}$ receptors (Sugimoto et al., 1993) and to native $\mathrm{EP}_{3}$ receptors in the renal, gastrointestinal and reproductive tissues from various nonprimate species (Sonnenberg et al., 1990; Watanabe et al., 1991; Woodward et al., 1994). In contrast, $\mathrm{PGD}_{2}$ exhibited minimal activity at the human $\mathrm{EP}_{3}$ variants, whereas, it is more active at some nonprimate $\mathrm{EP}_{3}$ receptors. Other differences in potency also exist between the cloned murine and human $\mathrm{EP}_{3}$ receptors. For example, MB28767 is $\sim 10$ fold more potent than $\mathrm{PGE}_{1}$ at the human $\mathrm{EP}_{3 \mathrm{~A}}$ as compared with the murine $\mathrm{EP}_{3 \alpha}$. In this regard, the murine $\mathrm{EP}_{3 \alpha}$ is more similar pharmacologically to the human $\mathbf{E P}_{3 \mathrm{E}}$.

The radioligand binding of $\left[{ }^{3} \mathrm{H}\right]-\mathrm{PGE}_{2}$ to membranes prepared from cells transfected with these $\mathrm{EP}_{3}$ receptors offers some distinct advantages over the use of naturally occurring animal tissues. For example, at a concentration of $5 \mathrm{nM}$ $\left.{ }^{3} \mathrm{H}\right]-\mathrm{PGE}_{2}, 35 \mu \mathrm{g}$ of membrane protein from COS-7 cells transiently transfected with the $\mathbf{E P}_{3 \mathrm{~A}}$ yielded $\sim 37,100$ d.p.m. of specific $\left[{ }^{3} \mathrm{H}\right]-\mathrm{PGE}_{2}$ binding activity $\left(3.2 \mathrm{pmol} \mathrm{mg}{ }^{-1}\right.$ protein) with only $2 \%$ nonspecific binding. Using membranes prepared from the rat uterus, $20 \mu \mathrm{g}$ of membrane protein yielded $\sim 2,100$ d.p.m. of specific binding ( $309 \mathrm{fmol} \mathrm{mg}^{-1}$ protein) with $33 \%$ nonspecific binding (Woodward et al., 1994). The recognition of $\mathrm{EP}_{3}$ receptor heterogeneity combined with the ability to study these variants in isolation increases the likelihood that the biochemical differences between these variants will be exploited pharmacologically.

The apparent differences in agonist binding between $\mathrm{EP}_{3}$ receptor variants could reflect differences in the efficiency of coupling, or pattern of coupling, to G-proteins and second messenger pathways. Native $\mathrm{EP}_{3}$ receptors, previously characterized in cells and tissues, inhibit adenylyl cyclase as part of their second messenger pathway (Sonnenburg et al., 1990; Matthews \& Jones, 1993). The mouse $\mathrm{EP}_{3}$ receptors that have been stably expressed in cultured CHO cells (Sugimoto et al., 1993) differ markedly in their inhibition of forskolinstimulated cyclic AMP formation. Thus, $\mathrm{PGE}_{2}$ is $\sim 3$ orders of magnitude more potent at the $\mathrm{EP}_{3 \alpha}$ than it is at the $\mathrm{EP}_{3 \beta}$. The isoforms also differ with respect to desensitization with the $E_{3 \alpha}$ being relatively sensitive and the $E_{3 \beta}$ resistant (Negishi et al., 1993). The human $\mathrm{EP}_{3}$ receptor variants also seem to show differences with respect to their patterns of coupling with adenylyl cyclase. In transiently transfected human JEG-3 cells there was a biphasic effect on forskolinstimulated cyclic AMP-responsive CAT reporter gene activity: first inhibition, and then reversal. It also appeared that sulprostone could produce a greater degree of inhibition at the $\mathrm{EP}_{3 \mathrm{~A}}$ as compared with either the $\mathrm{EP}_{3 \mathrm{D}}$ or $\mathrm{EP}_{3 \mathrm{E}}$.

Phosphorylation of G-protein coupled receptors on serines and/or threonines present in the carboxyl terminal or third intracellular loop is known to be critical in the process of receptor desensitization (Lefkowitz, 1993). In addition, tyrosines present in the carboxyl terminus of the $\beta$-adrenoceptor may have a role in the more specific process of down-regulation, although, it is unknown if this also involves phosphorylation (Valiquette et al., 1990). It is notable, therefore, that the composition of the carboxyl termini of the human $\mathrm{EP}_{3}$ receptor variants differ markedly in these regards. Thus, the carboxyl terminus of the $\mathrm{EP}_{3 \mathrm{~A}}$ contains 7 serines, 3 threonines and 2 tyrosines; the $\mathrm{EP}_{3 \mathrm{E}}$ contains none of these amino acids and the $\mathrm{EP}_{3 \mathrm{D}}$ contains 5 serines, 1 threonine and 1 tyrosine. If desensitization of $\mathrm{EP}_{3}$ receptors specifically involves phosphorylation of the carboxyl terminus, then the human $\mathrm{EP}_{3 \mathrm{~A}}$ and $\mathrm{EP}_{3 \mathrm{D}}$ would be expected to be more affected than the $\mathrm{EP}_{3 \mathrm{E}}$.

Very recently the cloning of four $\mathrm{EP}_{3}$ receptor variants $\left(\mathrm{EP}_{3 \mathrm{~A}}, \mathrm{EP}_{3 \mathrm{~B}}, \mathrm{EP}_{3 \mathrm{C}}, \mathrm{EP}_{3 \mathrm{D}}\right)$ from the bovine adrenal medulla was reported (Namba et al., 1993). Interestingly, all of these bovine isoforms were variants starting with the same amino acid in the carboxyl terminus as in the human variants; however, only one is an actual homologue of the human clones. Thus, the bovine $\mathrm{EP}_{3 \mathrm{D}}$, is a homologue of the human $\mathrm{EP}_{3 \mathrm{D}}$. The human $\mathrm{EP}_{3 \mathrm{~A}}$, which is a homologue of the mouse $\mathrm{EP}_{3 \alpha}$, is not a homologue of the bovine $\mathrm{EP}_{3 \mathrm{~A}}$. In addition, none of the bovine variants are homologues of the mouse $\mathrm{EP}_{3 \beta}$. In total, therefore, up to seven $\mathrm{EP}_{3}$ receptor variants may exist in any given species.

The identification and characterization of these $\mathbf{E P}_{3}$ receptor variants demonstrates a greater degree of complexity with respect to alternative RNA splicing than previously thought for the G-protein coupled receptors. It also raises intriguing questions concerning the regulation and expression of these isoforms and their physiological roles in mediating the actions of endogenous prostaglandins. The potential for tissue specific expression of each of the human $\mathrm{EP}_{3}$ receptor variants exists, as well as the possibility that the regulation of receptor number rests not only at the level of the protein but at the level of the mRNA. The differential expression of these $\mathrm{EP}_{3}$ receptor variants could affect a target tissue's sensitivity to drugs both in terms of responsiveness and the ability to desensitize. Such differences could potentially be exploited for therapeutic benefit.

Note added in proof

We have recently cloned a cDNA from a human skin fibroblast library (Clontech) that represents an additional carboxyl terminal variant of the $\mathrm{EP}_{3}$ prostaglandin receptor. This variant, the $\mathrm{EP}_{3 \mathrm{~F}}$, is related to the human $\mathrm{EP}_{3 \mathrm{E}}$ and probably explains the doublet that was observed in the PCR reaction (Figure 6, lane 11; also see paragraph 4 of Discussion). As compared with the $\mathrm{EP}_{3 \mathrm{E}}$ (Figure 2), the $\mathrm{EP}_{3 \mathrm{~F}}$ contains an additional 27 bases between nt's 1133 and 1134 . The nucleotide and deduced amino acid sequence of this insert is shown as follows. 


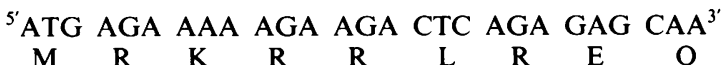

The radioligand binding and functional coupling of this variant have not been presently characterized.

\section{References}

COLEMAN, R.A., HUMPHREY, P.P.A. \& KENNEDY, I. (1982). Prostanoid receptors in smooth muscle: further evidence for a proposed classification. Trends. Autonom. Pharmacol., 3, 35-49.

COLEMAN, R.A., HUMPHREY, P.P.A., KENNEDY, I., SHELDRICKS, R.L.G. \& TOLOWINKSA, I.Y. (1987). Further evidence for the existence of three subtypes of $\mathrm{PGE}_{2}$-sensitive (EP-) receptors. $\mathrm{Br}$. J. Pharmacol., 91, 407P.

CULLEN, B.R. (1987). Use of eukaryotic expression technology in the functional analysis of cloned genes. Methods Enzymol., 152, $684-704$

DAL TOSO, R., SOMMER, B., EWERT, M., HERB, A., PRITCHETT, D.B., BACH, A., SHIVERS, B.D. \& SEEBURG, P.H. (1989). The dopamine $\mathrm{D}_{2}$ receptor: two molecular forms generated by alternative splicing. EMBO J., 8, 4025-4034.

FURCI, L., FITZGERALD, D.J. \& FITZGERALD, G.A. (1991). Heterogeneity of prostaglandin $\mathrm{H} 2 /$ thromboxane $\mathrm{A} 2$ receptors: distinct subtypes mediate vascular smooth muscle contraction and platelet aggregation. J. Pharmacol. Exp. Ther., 258, 74-81.

GILES, H., LEFF, P., BOLOFO, M.L., KELLY, M.G. \& ROBERTSON, A.D. (1989). The classification of prostaglandin DP-receptors in platelets and vasculature using BWA868C, a novel, selective and potent competitive antagonist. Br. J. Pharmacol., 96, 291-300.

GIROS, B., SOKOLOFF, P., MARTRES, M.-P., RIOU, J.-F., EMORINE, L.J. \& SCHWARTZ, J.-C. (1989). Alternative splicing directs the expression of two $\mathrm{D}_{2}$ dopamine receptor isoforms. Nature, 342, 923-926.

GIROS, B., MARTRES, M.-P., PILON, C., SOKOLOFF, P. \& SCHWARTZ, J.-C. (1991). Shorter variants of the $D_{3}$ dopamine receptor produced through various patterns of alternative splicing. Biochem. Biophys. Res. Commun., 176, 1584-1592.

HIRATA, M., HAYASHI, Y., USHIKUBI, F., YOKOTA, Y., KAGEYAMA, R., NAKANISHI, S. \& NARUMIYA, S. (1991). Cloning and expression of cDNA for a human thromboxane $A_{2}$ receptor. Nature, 349, 617-620.

HONDA, A., SUGIMOTO, Y., NAMBA, T., WATABE, A., IRIE, A., NEGISHI, M., NARUMIYA, S. \& ICHIKAWA, A. (1993). Cloning and Expression of a cDNA for mouse prostaglandin E receptor $\mathrm{EP}_{2}$ subtype. J. Biol. Chem., 268, 7759-7762.

JONES, S.V.P., HEILMAN, C.J. \& BRANN, M.R. (1991). Functional responses of cloned muscarinic receptors expressed in $\mathrm{CHO}-\mathrm{K} 1$ cells. Mol. Pharmacol., 40, 242-247.

LEFKOWITZ, R.J. (1993). G protein-coupled receptor kinases. Cell, 74, 409-412.

LINK, R., DAUNT, D., BARSH, G., CHRUSCINSKI, A. \& KOBILKA, B. (1992). Cloning of two mouse genes encoding $\alpha_{2}$-adrenergic subtypes and identification of a single amino acid in the mouse $\alpha_{2}-\mathrm{C} 10$ homolog responsible for an interspecies variation in antagonist binding. Mol. Pharmacol., 42, 16-27.

MASUDA, A., MAIS, D.E., OATIS, J.E \& HALUSHKA, P.V. (1991) Platelet and vascular thromboxane $A_{2}$ /prostaglandin $\mathrm{H}_{2}$ receptors: evidence for different subclasses in the rat. Biochem. Pharmacol., 42, 537-544.

MATTHEWS, J.S. \& JONES, R.L. (1993). Potentiation of aggregation and inhibition of adenylate cyclase in human platelets by prostaglandin E analogues. Br. J. Pharmacol., 108, 363-369.

MCPHERSON, G.A. (1985). Analysis of radioligand binding experiments: a collection of computer programs for the IBM PC. $J$. Pharmacol. Methods, 14, 213-228.

MONSMA, F.J., MCVITTIE, L.D., GERFEN, C.R., MAHAN, L.C. \& SIBLEY, D.R. (1989). Multiple $\mathrm{D}_{2}$ dopamine receptors produced by alternative RNA splicing. Nature, 342, 926-929.

NAMBA, T., SUGIMOTO, Y., NEGISHI, M., IRIE, A., USHIKUBI, F., KAKIZUKA, A., ITO, S., ICHIKAWA, A. \& NARUMIYA, S. (1993). Alternative splicing of C-terminal tail of prostaglandin $\mathrm{E}$ receptor subtype EP3 determines G-protein specificity. Nature, 365, 166170.
This work has been supported by Allergan Inc. with additional support provided to J.W.R. by the National Institutes of Health (EY09355), the Arizona Affiliate of the American Heart Association and the Arizona Disease Control Research Commission.

NEGISHI, M., SUGIMOTO, Y., IRIE, A., NARUMIYA, S. \& ICHIKAWA, A. (1993). Two isoforms of prostaglandin $E$ receptor $E_{3}$ subtype: Different $\mathrm{COOH}$-terminal domains determine sensitivity to agonist-induced desensitization. J. Biol. Chem., 268, 9517-9521.

OKSENBERG, D., MARSTERS, S.A., O'DOWD, B.F., JIN, H., HAVLIK, S., PEROUTKA, S.J. \& ASHKENAZI, A. (1992). A single aminoacid difference confers major pharmacological variation between human and rodent 5-HT $1 \mathrm{~B}$ receptors. Nature, 360, 161-163.

PEPPERL, D.J. \& REGAN, J.W. (1993). Selective coupling of $\alpha_{2}$ adrenergic receptor subtypes to cAMP-dependent reporter gene expression in transiently transfected JEG-3 cells. Mol. Pharmacol., 44, 802-809.

REGAN, J.W., KOBILKA, T.S., YANG-FENG, T.L., CARON, M.G., LEFKOWITZ, R.J. \& KOBILKA, B.K. (1988). Cloning and expression of a human cDNA for an $\alpha_{2}$-adrenergic receptor subtype. Proc. Natl. Acad. Sci. U.S.A., 85, 6301-6305.

SAMBROOK, J., FRITSCH, E.F. \& MANIATIS, T. (1989). In Molecular Cloning: a Laboratory Manual, Cold Spring Harbor, NY: Cold Spring Harbor Laboratory Press.

SONNENBURG, W.K., ZHU, J. \& SMITH, W.L. (1990). A prostaglandin E receptor coupled to a pertussis toxin-sensitive guanine nucleotide regulatory protein in rabbit cortical collecting tubule cells. $J$. Biol. Chem., 265, 8479-8483.

SUGIMOTO, Y., NEGISHI, M., HAYASHI, Y., NAMBA, T., HONDA, A. WATABE, A., HIRATA, M., NARUMIYA, S. \& ICHIKAWA, A. (1993). Two isoforms of the $\mathrm{EP}_{3}$ receptor with different carboxylterminal domains: identical ligand binding properties and different coupling properties with $\mathrm{G}_{\mathrm{i}}$ proteins. J. Biol. Chem., 268, 2712-2718

SUGIMOTO, Y., NAMBA, T., HONDA, A., HAYASHI, Y., NEGISHI, M., ICHIKAWA, A. \& NARUMIYA, S. (1992). Cloning and expression of a cDNA for mouse prostaglandin $\mathrm{E}$ Receptor $\mathrm{EP}_{3}$ Subtype. $J$. Biol. Chem., 267, 6463-6466.

TAKEUCHI, K., ABE, T., TAKAHASHI, N. \& ABE, K. (1993). Molecular cloning and intrarenal localization of rat prostaglandin $\mathrm{E}_{2}$ receptor $\mathrm{EP}_{3}$ subtype. Biochem. Biophys. Res. Comm., 194, $885-891$.

VALIQUETTE, M., BONIN, H., HNATOWICH, M., CARON, M.G., LEFKOWITZ, R.J. \& BOUVIER, M. (1990). Involvement of tyrosine residues located in the carboxyl tail of the human $\beta_{2}$-adrenergic receptor in agonist-induced down-regulation of the receptor. Proc. Natl. Acad. Sci. U.S.A., 87, 5089-5093.

WATANABE, T, SHIMIZU, T., NAKAO, A., TANIGUCHI, S., ARATA, T., TERAMOTO, T., SEYAMA, Y., UI, M. \& KUROKAWA, K. (1991). Characterization of partially purified prostaglandin $E_{2}$ receptors form canine renal medulla: evidence for physical association of the receptor protein with the inhibitory guanine nucleotide-binding protein. Biochem. Biophys. Acta, 1074, $398-405$.

WOODWARD, D.F., FAIRBURN, C.E. \& LAWRENCE, R.A. (1994). Identification of the FP-receptor as a discrete entity by radioligand binding in biosystems that exhibit different functional rank orders of potency to prostanoids. In Eicanosoids and Other Bioactive Lipids in Cancer, Inflammation, and Radiation Injury, (In press).

WOODWARD, D.F., SPADA, C.S., HAWLEY, S.B., WILlIAMS, L.S., PROTZMAN, D.C. \& NIEVES, A.L. (1993). Further studies on ocular responses to DP receptor stimulation. Eur. J. Pharmacol., 230, $327-333$

(Received November 15, 1993 Revised January 27, 1994 Accepted February 3, 1994) 